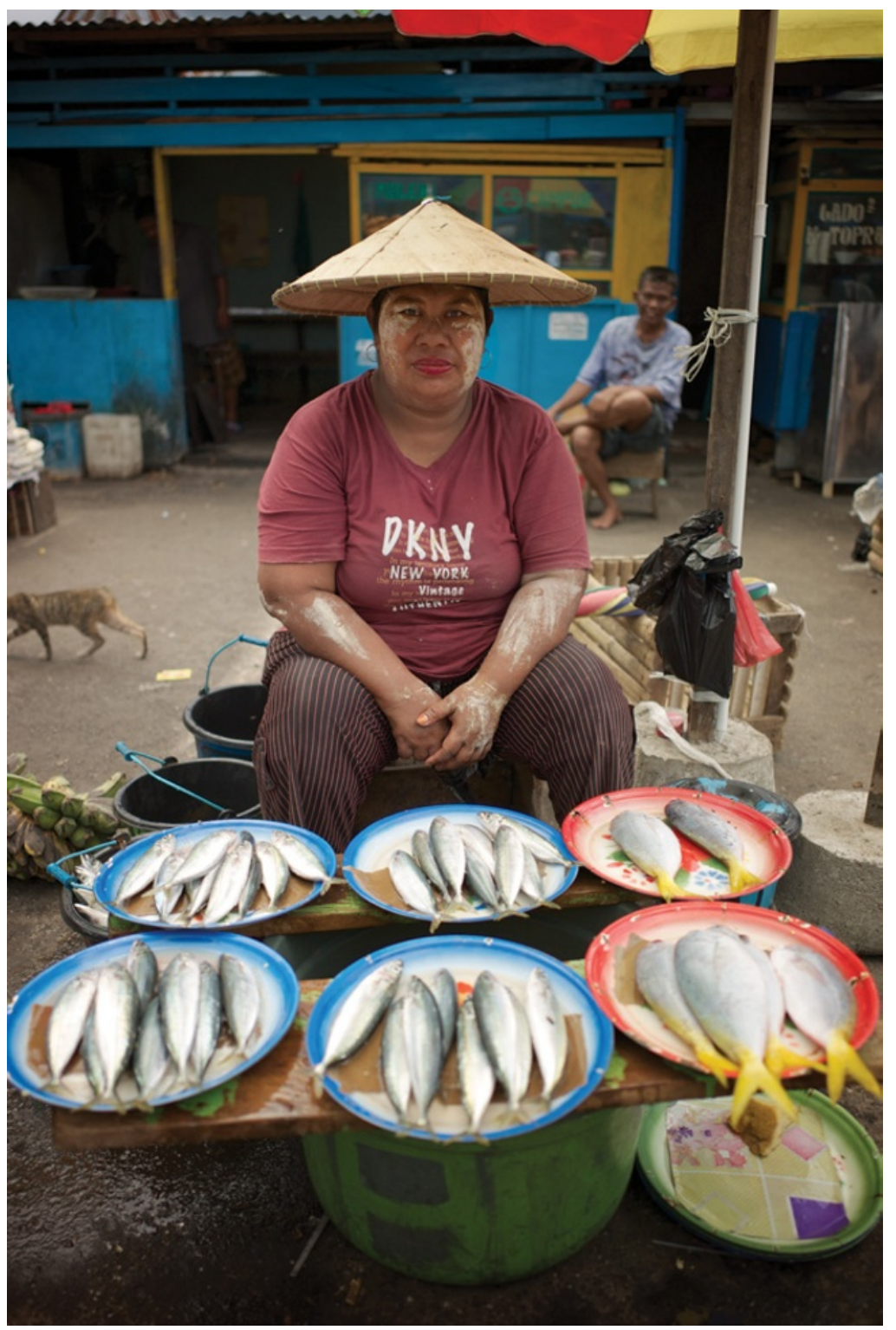

Fig. 2. TERNATE: A fishmonger at the central market and bus terminal poses with her stock. She's fashionably outfitted against the midday sun with a broad hat and smears left by a thin rice-flour-and-turmeric paste applied earlier to protect her skin; alas, her fish boast no similar protection from the heat. June 2010: photo by S. Chris Brown 


\title{
WORKING CLASS REVISITED: CLASS RELATIONS IN INDONESIAN PROVINCIAL TOWNS
}

\author{
Nicolaas Warouw
}

Class analysis in Indonesia has reached an impasse, from which it can be released by opening our eyes to urban anthropology. Class analysis should be made more concrete by situating it in the geography of urban community. The typically Indonesian kampung has been described as an 'urban society of the common people' (Dick 1985:75), distinguished by 'social harmony and co-operation' (Guinness 1986:184; also J. Sullivan 1992). Most members of the industrial working class live in such a kampung. In almost every aspect of their life, including their work, they have to craft relationships with members of other urban classes who live around them. I argue that the working-class sense of injustice emerges not only from industrial practices, but also from the urban vulnerabilities that they share with other urban classes whose life chances are limited. It is generated by the social heterogeneity of the locality and by the workers' identification with their communities. These form an imminent energy within the working class. When members of other classes also experience dispossession and marginalization, a working-class consciousness in semi-urban industrial centres might arise.

Democratization since the late 1990s has brought unprecedented political participation to local agents in the peripheries. Residents of distressed kampung communities have engaged in political struggle to gain access to basic state services. In the process they often contested the authority of existing cultural leaders who had long benefited from the intermediary roles they played in patronage relations.

This chapter examines working-class communities in two industrial towns, both on the coast. Cilegon is located in western Java with a population in 2008 of 346,059 , and Pekalongan in central Java with a population in 2005 of 267,574. Manufacturing is the context for working-class local politics. Residents blame local notables and low-level state officials, whom they call 'elites', for poor implementation of urban policy. After the political reform following the downfall of Suharto in 1998, elites have benefited most from decentralization. The spread of power and resources to provincial towns has empowered local elites. This centralization of power in the 
hands of local elites is making the access to welfare schemes more difficult. This has prompted some industrial-labour activists to look for support among marginalized urban groups to claim welfare rights. Labour activists campaign on environmental and employment issues that affect the whole community. While many scholars of regional autonomy remain focused on elites (for instance, Webster, Stokke and Tornquist 2009:2256), this chapter suggests that urban-neighbourhood democracy is a promising (if still underdeveloped) form of popular engagement. Democracy at this level is dynamizing both local class formation and culture-based social configurations.

Beginning with the heterogeneous class structure of local communities in these two urban industrial centres, the chapter then describes how some industrial workers adopted unusually active roles on behalf of their deprived local community. Their engagement in community-based social struggles amounted to an expression of class.

\section{Geography}

Most Indonesian cities with an industrial working class did not emerge from an industrial economy. There are exceptions, such as the nickelmining town of Soroako in Sulawesi (Robison 1986), or the copper- and gold-mining towns of Tembagapura and Timika in Papua (Aditjondro 1982; Widjojo 1997), but manufacturing mostly grew up on the outskirts of towns in agrarian settings, aiming to benefit from the abundant supply of labour in the countryside (Mather 1983; Ratna Saptari 1995; Weix 1990). Low industrial wages were considered acceptable by people still part of a family economy (Wolf 1992). Cultural values fostering labour docility remained strong. This made rural areas ideal settings for manufacturing. State officials also had reasons to move industries away from metropolitan centres towards neighbouring rural towns. The big cities were overpopulated, already flooded with investment, and moreover threatened by political instability due to labour unrest. This explains the relocation of factories from Jakarta, west to Tangerang and east to Bekasi, during Suharto's New Order (Giebels 1983; Hadiz 1997; Stolte 1995). Already during the Sukarno era, the state-led industrialization of the rural town of Cilegon was motivated by the need to contain local 'disobedience' towards the central government and to break down 'political parochialism' (Hikam 1995; Amri Marzali 1976).

Thus industrial centres with semi-urban characteristics were rapidly established in the midst of agrarian communities. Existing social relations 
embodied in local neighbourhoods often remained surprisingly intact. The industrial working class was born in this hybrid environment. Much of the scholarly literature on labour in Indonesia is misdirected for overlooking this geographical setting. Those studies that have described a working class estranged from other urban classes, and indeed from the dominant classes in general, have missed this local-community context. We can think of descriptions of industrial workers as 'prisoners' (Harris 1995) of the country's economic development, who find release in their defiance of unfair work practices and the political repression of labour. This is made possible through workers' solidarity, occasionally in alliance with progressive urban middle class elements such as students, lawyers, academics and NGO activists (for instance, Ford 2009; Hadiz 1997; Kammen 1997; La Botz 2001). The energy that the working class obtain from their local community disappears from such accounts. Having an eye for working-class engagement with other marginalized classes is also part of Herring and Agarwala's (2006) agenda for 'restoring agency to class' analysis in India.

The literature on labour in Indonesia has overwhelmingly concerned itself with labour conditions on the shopfloor; class consciousness emerges from control and resistance at the point of production. However, rather than focus exclusively on the world of work, we would gain more by expanding our view. Ratna Saptari (2003:135-6) did do this when she analysed the impact of the piece-work system by examining the impoverished urban enclave where workers live. She also explained the lack of industrial strife and the acceptance of strong workplace hierarchy by referring to the patriarchal values prevailing in the residential neighbourhood. Class is a life condition shaped by local residential relations as much as by working conditions. This view is in line with Eric Hobsbawm's (1984) 'worlds of labour' extending to the domain of values, ideologies and everyday existence in the 'natural habitation' of the workers.

\section{The Social Structure in Local Community}

Most of Pekalongan's medium-sized manufacturing establishments, and all of Cilegon's industrial estates, are on the margins of town. The local communities that host the factories and house the workers are socially heterogeneous. While downtown residential areas house people engaged in modern services, trade and public office, the communities on the periphery are shared by people from more varied walks of life. They include farmers, fishers and other non-modern sectors whose numbers 
continue to decline but who never manage to make the transition to modern and formal sectors. Small traders, food stall proprietors and other informal service workers help further broaden the neighbourhood social configuration.

Industrial workers made up $21.59 \%$ of all workers in Cilegon in 2008 and $21.83 \%$ in Pekalongan in 2005. Of these, the permanent workers were the most secure, just below managers and supervisors. Most are educated and skilled, and hold responsible positions in administration and production. They enjoy the full protection of labour rights stipulated in work agreements, their salaries are well above the government-set minimum wage and, in addition, they get a variety of allowances and bonuses. In Cilegon, these position are believed mostly to be filled by 'migrants' from elsewhere in Java and from the nearby island of Sumatra. Though there are no official statistics on the ethnic composition of industrial workers, Muhammad Hikam (1995:385) reported that only a 'handful' of local people occupied such positions. Workers interviewed for this research confirmed that ethnic tensions between locals and migrants in the workplace are common. ${ }^{1}$ The migrant workers mostly rent rooms in barrack-like housing owned by locals. This type of accommodation rather separates the migrants from the everyday life of the local community, to which, by contrast, the local workers are constantly exposed. In Pekalongan such barrack-like housing does not exist, and all workers share a house with local owners or acquire an individual house. They identify with the local community and engage in its problems, and this makes them want to stay on. In both towns, despite describing themselves as 'mere operators', the permanent workers with local identification managed to complete their education, whether high school, vocational school, non-degree or an undergraduate qualification in relevant disciplines. This enables them to handle complex machinery and hazardous chemicals in the factories of Cilegon as production operators, liquid waste controllers, or laboratory analysts. One of my Pekalongan informants had been to a vocational school in textile technology to learn specialized spinning techniques.

\footnotetext{
${ }^{1}$ Informants generally admitted that the locals' lack of relevant skills and education may explain the company's preferences for migrants. But Hikam (1995:348) concluded that managers adhered to a stereotyped idea that migrants were 'more docile and less demanding' than locals. Locals felt cheated out of land compensation by the establishment of new industries during the 1970s (see also Amri Marzali 1976:34-6). Moreover, Cilegon was the site of a peasant rebellion in 1888 and a communist uprising backed by Islamic religious leaders in 1926, both against Dutch colonial rule. Social revolution against local bureaucrats between 1945 and 1949 strengthened the rebellious stereotype attached to the locals (see also Kartodirdjo 1966 and M. Williams 1982).
} 
He was head-hunted by a large textile company even before finishing the course. His employer asks him frequently to travel inter-city to examine raw materials. These established workers enjoy good, secure salaries and are respected within their local communities for this. ${ }^{2}$

Unlike the permanent workers, contract workers are linked to industry only by a third-party company in an outsourcing arrangement. Liberalization has made this increasingly important. Official labour figures do not include this type of labour, but PT Krakatau Steel, the country's largest steel manufacturer and based in Cilegon, had nearly 4,0oo contracted workers supplied by four employment contractors in 2010. This number is set to go up when production expands under a new joint venture with one of South Korea's largest steel producers. Outsourcing contracts are likely to be signed with nine contractors. Outsourced workers perform regular jobs, ranging from non-production tasks (e.g. office boy, cleaner, gardener) to production work on the shopfloor. They are therefore at the bottom of the workplace hierarchy - not because of their job descriptions, but as a consequence of the unprotected nature of their labour. They fall outside any labour law by which the employer or the state could be held responsible. In one Cilegon industrial neighbourhood I examined, an official village-level youth organization called Karang Taruna recruited factory workers from the local community, but gave them no formal contract. There is a case where a company made a deal with a unit within the state administration office at the village level. Most of the industrial workers identifying as local were in this category. They have no access to the normal mechanism of promotion, nor to decent workplace treatment such as safety gear, a uniform and meals, nor the bonuses, allowances, pension fund or even the minimum wages regular workers enjoy. ${ }^{3}$ The neighbourhood in the north-west of Pekalongan that I studied, meanwhile, had no outsourced labourers (although outsourcing is important in the textile industries in Pekalongan's centre and south). ${ }^{4}$

2 The skilled migrant workers in Cilegon described by Rudnyckyj (2008), by contrast, lived in secluded neighbourhoods provided by their employer. This focus prevented them from being curious about the local community.

3 Contracted workers receive only a daily or monthly salary to cover living costs. Moreover, they are only eligible for medical treatment from health clinics, whose service is claimed by informants to be below standard. However, a serious work accident may allow them to access medical treatment from a hospital.

${ }^{4}$ Contracting arrangements are, in fact, typical of batik small and home industries throughout Pekalongan (Chotim 1994). The decline of local entrepreneurs due to the repeal of the state's protection policy over raw materials in 1970, as Robison (1986) and 
Most workers were migrants from neighbouring towns looking for cheap housing. The north coast, with its fisheries, is vulnerable to tidal flooding.

Urban neighbourhoods also house other types of labourers who contribute indirectly to the manufacturing activity. Contractors ${ }^{5}$ often hire unskilled locals on a casual basis to paint or repair factory buildings or to overhaul machinery. For locals to get work like this they must have good relations with one of the local personalities connected to the recruiting agency or organization. Manufacturers frequently offer casual recruitment concessions to such local figures as part of their corporate social responsibility (CSR). This personalizes the relation between society and capital, something to which we will return.

When not being hired, such casual labourers are doing 'favours' for people in the neighbourhood - helping one neighbour find a truck to transport construction material, fixing the roof for another neighbour. All this in exchange for petty cash, known as a komisi (commission) and ostensibly to pay for cigarettes, motorbike petrol or a mobile phone voucher. Some young people make illegality an option. Locals in Cilegon use the slang word nyekrap (possibly from the English 'scrap') to refer to thieving scrap metal from the industries, for sale in the local black market. They have also been known to target steel poles and telephone cables passing through their own neighbourhoods, arguing these were being used more by industry and government than by the locals.

Of course manufacturing is not the only job provider in the community. In one Cilegon neighbourhood I saw home workers producing mlinjo crackers (a traditional snack made from mlinjo nuts) for local small entrepreneurs called juragan emping. Most were housewives and young women, contracted to work in their own homes at piece-rates. The entrepreneur would come in the late afternoon to collect the crisps, pay and leave fresh raw mlinjo for the following day's production. He employed

Muhaimin (1991) point out, led to the closure of batik enterprises in some parts of Pekalongan. The introduction of printing technology in batik making, enabling the cost of production to fall, but leaving the capital only in the hands of a small number of big entrepreneurs, including the Indo-Chinese, exacerbated the situation whereby smaller actors, unable to contest in the competition, ceased their operation. Today, the clusters of batik industries are concentrated in the central part down to the southern area of Pekalongan. I am indebted to Amalinda Savirani for her insights on Pekalongan's batik entrepreneurs and the geographical spread of the industry.

5 In some cases, the term 'contractor' may seem too 'industrialized', given that the role is often filled by local organizations, such as the Karang Taruna (youth group) affiliated to the village administration. When such an organization recruits for an industrial company, the workers have even less protection than those recruited by a bona fide outsourcing company. 
around two hundred workers. In a coastal neighbourhood of Pekalongan workers in small-to-medium-scale fisheries-related industries were making block ice, processing canned or salted fish and building wooden boats. Local entrepreneurs supplied the local fishing economy and a town-wide market. In both towns these home industries were largely informal; their compliance with government fiscal and labour regulations was limited. ${ }^{6}$ Businesses are registered, have permissions from the municipal authority and can receive local bank loans, but they pay below-minimum wages and provide insufficient labour protection. Workers in such an economy are best categorized as informal. The category extends to the alreadymentioned contract workers and casual labour in large industries.

Both towns have a considerable number of small-scale fishers in coastal neighbourhoods. Particularly in Pekalongan, they enter into a profitsharing arrangement with owners of large and more powerful boats, allowing them to sail to deep water for bigger catches. The downside is that they thereby lose their connection with the local fish-processing industries, which refuse to buy from profit-sharing fishers because they ask a higher price. As a result, these fishers can only sell their catch at the municipal auction centre, where extortion is rife. Declining profits have forced some of them to shift to land fishery (ponds and rivers) where they can sell to the more profitable local fisheries-related industries. The Cilegon fishing economy is even smaller. There fishermen have no connection with local entrepreneurs. Their small boats with weak engines yield small catches in shallow water. A more powerful engine requires a special licence from the government fisheries authority. Locals believe chemical run-off has caused coastal fish stocks to decline. They have limited room to manoeuvre among the huge industrial ships and tankers and the commercial ferries running to Sumatra. Moreover, industrial plants block most road access to the coast, making it difficult for fishermen to transport their catch to market. As a result, price-fixing middlemen who connect fishers with the market have become increasingly crucial to their survival.

Cilegon's small farmers also need the middlemen, whom they call 'big boss'. Half of the town's surface area is covered by hilly forest and agricultural landscapes. When the municipal authority relocated the local markets away from the farming neighbourhood to downtown, these farmers found it hard, financially and psychologically, to sell their products at the

${ }^{6}$ For the definition of 'informal sector', see Portes, Castells and Benton 1989 and Agarwala 2006:420-2. 
new, more distant market. The farmers also experience declining production. They blame air pollution and contaminated water on Cilegeon's industries.

Moving up the social ladder, there are 'elite' classes within the local community who do have a more direct relationship with formal business, such as the industrial companies, and with the lower state bureaucracy at the municipal administration. Among them are the crisps-making entrepreneurs and labour-contracting agencies in Cilegon, and the large boatowners in Pekalongan. Cilegon's heavy industries also grant community concessions to recycle industrial solid waste as a gesture of corporate social responsibility. ${ }^{7}$ But only 'strong men' (orang kuat) have the finance and connections to benefit from the recycling business. This marks the rise of entrepreneurs who deploy their local identity and claim to represent the locals to gain contracts from the surrounding large industries. They provide services ranging from labour supply, overhaul and repair works to waste recycling and office supplies.

Such entrepreneurs come not only from the private sector but also from local officialdom. One recycling concession was offered to a senior village official in Cilegon. Corporate contracts become slush funds for local power struggles. A 2004 law on local government stipulates that lower officials can only be appointed by the mayor or district head. In practice this means the village apparatus has become part of the political machine of the incumbent local head of government. During the mayoral election in Cilegon in early 2010, residents deplored the inclination of village officials to direct people to vote for the incumbent's preferred candidate. ${ }^{8}$ In a bid to build political allegiances, municipal-level officials and politicians have pushed through regulations directing industries to channel contracts and CSR schemes to 'local' interests. Local entrepreneurs interested in concessions from surrounding large companies consequently need to demonstrate adherence to political elites and municipal officials. Success depends on their ability to build connections between the neighbourhood and the municipality. This web of entrepreneurs and officials appears to be typical to Cilegon. The small entrepreneurs on

7 During the political turmoil in 1998, the locals ransacked the surrounding factories and looted metal bars, pipes, iron fences or other large objects considered to have economic value. This was caused by social and economic disparity in Cilegon, where the locals felt that they were not the direct beneficiaries of the town's industrialization. The CSR programme grew out of that period.

8 The mayor, by law, was not allowed to run as he was already in his second term. The mayor's preferred candidate, who was in fact his son, won the election. 
Pekalongan's coast have no such web and are thus less dependent on state officials.

Other important figures in the social structure of the urban neighbourhood are those with social and cultural authority. In both towns there are Islamic religious leaders known as kyai, and in Cilegon there is the 'traditional' role known as jawara, or martial hero. Cilegon lies in Muslimmajority Banten, where the kyai have always combined religious authority with a degree of political power. Even today they have to negotiate between community expectations and their own need for power, as I will show below. Jawara is an informal leader and a traditional title in Bantenese society conferred upon a person considered to have the capacity (often related to martial arts) to protect the community from disruptive external forces. ${ }^{9}$ A tendency to put their own interests above those of the community led Oji Armuji (2004:93) to identify their modus operandi with the words 'anarchism' and 'pragmatism'. Their capacity to mobilize pressure using threats and violence has made jawara targets for recruitment by powerful forces in Cilegon who need to control popular criticism (Armuji 2004:94; Hikam 1995). Some jawara today are functionaries of the incumbent mayor's political party. Others have become entrepreneurs who pressure large companies for business concessions 'on behalf of the community'.

Such threats and violence can also be observed in Pekalongan, but there they are less connected with the bureaucracy. The decline of the fishing economy caused by extortion in the municipal markets, mentioned briefly earlier, is connected with the so-called 'land people' (orang darat). The term lumps together a range of intermediate actors spread out all along the way, from the point the fishermen dock their boat after returning from the sea, to the fish auction centre. They include temporarily unemployed local sailors and fish trolley porters. Petty gangsters and fixers claim to be responsible for 'security' in the area and for the 'smooth operation' of the fishing activity. Fishermen complain that their catches have been reduced to half by the time they arrive at the auction centre. This chain of extortion got so bad that it discouraged large boat-owners, with whom the fishermen had entered into a profit-sharing deal, from

9 During colonial times, the jawara was a leader and single fighter who protected the interests of local people or 'local tentants' in a bonded community in their resistance against the Dutch or 'private estate owners' (Shahab 2001:1-3; see also Abeyasekere 1987:67). My past study in Tangerang reveals the connection of jawara to manufacturing industries that use them to control labour activism in the neighbourhood (Warouw 2006). 
dispatching their fleets. Fishing profits declined until owners were only able to recover basic expenses.

\section{The Intermediate Classes and their Adversaries}

Barbara Harriss-White (2003:241) deploys the term 'intermediate classes' to describe 'a loose coalition of the small-scale capitalist class, agrarian and local agribusiness elites, and local state officials' typically found in Indian country towns. The coalition aims to gain access to 'state resources' and 'concessions by influencing policy in its implementation'. Gerry van Klinken (2009:888), speaking of Indonesia, characterizes these classes by their 'non-market mechanisms such as patriarchy, ethnic and religious solidarity, and the threat of violence'. All these techniques have the potential to undermine the authority of the state by converting government policies and subsidies for their own benefit. In fact, he continues, their 'mobilizing skills' have been used by the state to reinforce the presence of the state and to endorse the government's policies in exchange for rewarding concessions.

The term 'intermediate classes' applies well to the local elites we have described above. In Cilegon, the capacity of the intermediate classes to control the economy at the neighbourhood level is evident in different forms. These intermediary classes have the capacity to arrange the supply of labour to companies, and furthermore they benefit from their priviliged access to state institutions. The money they earn supports their dominance within the community.

The term 'intermediate classes' in the first place covers local state officials, who are typical intermediaries extending the administrative authority of the state to the population. But at the same time their access to the local community allows them to arrange employment opportunities at newly established companies. These officials have leverage with higher municipal authorities to make regulations directing corporate contracts to these companies. It is this capacity to craft beneficial regulations that forces local entrepreneurs to maintain personal connections with them; this includes financial sponsorship for electoral campaigns. Thus the rentseeking partnership of entrepreneurs, government officials and the corporate CRS managers rests on non-market mechanisms, particularly the skills to maintain social relations that enable the manipulation of state regulation.

In the second place the term intermediate classes is appropriate for certain religious and traditional leaders in these two towns. The use of 
cultural and traditional symbols to secure resources from the state and the companies is apparent in their capacity for threats and violence. Kyai who lead Islamic organizations enjoy access to state funding for religious activities and prayer facilities open to the whole community. Community figures such as jawara get funding from local officials essentially to curb community discontent. Such figures are vital to secure votes for the town's higher elites. Those considered jawara can ask the politicians at election time for anything they wanted, and they can also ask freely from the companies, in exchange for 'protection. ${ }^{10}$ Success enhances their authority in the community - they have cultural capital and the skills to pull resources from the state and from industry.

Despite their evident success, these actors who profit from 'non-market mechanisms' are often in conflict with other small local capitalists - those who do live by their market skills, who are less dependent on state agencies and large companies. In Pekalongan, the boat-owning entrepreneurs were annoyed with them for extorting the fishing economy nearly to death by their threats and violence. The extortion was particularly visible given, as described by some local informants, that these actors had connections with officials in the village administration who benefit from such practice. The result was the virtual extinction of coastal fisheries in Pekalongan. The Cilegon crisps-making entrepreneurs similarly could not decline when jawara asked for 'protection' money. Local officials made things worse by refusing to help unless offered more money. This type of conflict led some local entrepreneurs to enter into collaboration with lessprivileged social forces in the urban community. It is to this collaboration that we now turn, since it brings the workers back into view.

\section{Cilegon}

During Cilegon's 2010 local elections, a number of crisps-making entrepreneurs allied with their home workers to support a rival to the mayor's preferred candidate, whose nickname was Mumu. They hoped a new mayor independent of the current one would lower barriers to their business created by jawara and local officials. In short, they hoped for a democratic escape from the political machine of the town's dominant intermediate class elites. They particularly directed their challenge at local-neighbourhood agents loyal to the incumbent mayor. Here their efforts converged with a separate electoral effort initiated by some industrial workers

10 In Cilegon they also run lucrative informal 'protection' services for industries, stores, the seaport, bus terminals and traditional markets (Armuji 2004:93). 
resident in the same neighbhourhood. The workers had their own complaints against the ruling intermediate classes, namely that the latter were seizing state welfare schemes and social programmes for themselves and their cronies that were intended for the whole community.

These workers, employed full-time in the town's heavy industries, had begun holding informal gatherings after their day in the factories. In the beginning, these meetings were aimed at responding to moves made by the incumbent mayor's political party in the run-up to the 2009 parliamentary election. They brought together unemployed young people and industrial contract workers. The talk was about the problems with the local 'elites' - referring locally to politicians, officials and jawara - about unemployment, and the gap between locals and migrants. One of the workers, Affan, told me at the time that the forum had no intention to form an organization and only wanted to encourage young people not to become aggressive every time they encountered problems. He wanted the forum to transform 'local boys' (anak kampung), who displayed the aggressive behaviour regarded as typical of the Bantenese, into citizens with broader insights into the way they could respond to industrialization and modernization in their town. ${ }^{11}$

When I attended one of these meetings it struck me as interesting how clearly these underprivileged residents saw all the 'elite' (intermediate class) social forces - the rent-seeking entrepreneurs, the kyai, the jawara and the local officials - as obstacles to their own access to the state. They realized that the opportunities for employment, for access to welfare schemes such as health insurance and subsidized rice, and for participation in CSR programmes, were only available to those prepared to become clients to those that I have here called the intermediate classes, or sometimes 'elit' (elites), as my informants put it to me. Despite low educational achievement and locality-bound insights, these young unemployed people refused to be contained by the local elites whose lives were so conspicuously distinct from the rest of the population. They were angry about having been stigmatized by the elites as 'sinners' (murtad) and 'rubbish' (sampah) for their acts of petty crime. They realized the resources in elite hands were being devoted merely to personal ambition and to buy

${ }_{11}$ Most of the young, unemployed locals remained engaged in their small world of Cilegon, despite the easy transport possibilities to Jakarta or Sumatra. One of my unemployed informants had never even travelled outside of Banten province. One worker told me he believed marginalized young men in his neighbourhood engaged in thieving and thuggery because they had never travelled. 
loyalties. Others expressed disappointment with them for failing to set up a labour training centre in the neighbourhood to improve the chances of the unemployed. Contract labourers wanted better employment conditions in surrounding manufacturing establishments. A permanent position is regarded as ideal employment by residents in the urban industrial neighbourhood, not only because of the better conditions, but because it would release them from the patronage (kekuasaan) of the intermediate classes. All this amounted to criticism of the incumbent mayor for failing to prioritize secure industrial employment in the neighbourhood. Instead, he had been busy extending his patronage throughout the town.

Eventually these informal gatherings turned to spontaneous political action. During the 2009 general legislative elections, the residents split their votes to undermine Golkar, the party of the incumbent mayor. Golkar had been the dominant party since long before the 1998 reformasi, and even in 2009 the party had offered them money in exchange for their vote; but 2009 marked the end of the party's supremacy in the neighbourhood. This local experiment in bringing together an alternative coalition to challenge the incumbent mayor and his intermediate classes was repeated during the mayoral election of 2010. As the local workers put it, they wanted 'to humiliate' (mempermalukan) the circles close to the incumbent mayor for failing to provide for those on the margins. ${ }^{12}$

In another initiative in the same neighbourhood, a group of residents protested against environmental contamination by certain industries. They were upset that members of the local assembly neither visited the area immediately following a particularly significant leak of gases from the production process into the air, leaving local residents with respiratory problems, nausea and dizziness, nor even made a statement regarding the incident. ${ }^{13}$ The group was initiated by workers from the same chemical factory that caused the leak. It accused local officials of making a backdoor agreement with the company. A worker from the group, Dedi, said that local 'elites' with vested interests in the industries were always the biggest obstacle to solving pollution problems. This made them uninterested in mediating between residents and the company over contamination. The group did not want to challenge the companies and the state

12 The preferred candidate of the mayor (it was his son) still won, but only with $45.6 \%$ of the vote, much less than before. The residents felt anything below $50 \%$ was a major blow. The closest contender, a local entrepreneur popular amongst neighbourhood residents, managed to reap $36.13 \%$.

13 News items on www.Liputan6.com, 16 December 2009. 
but simply wanted greater access to resources made available by the industries and the government, and thus form a bridge between the locals and the companies. Their position as workers in those units that were directly related to production ensured they had sufficient knowledge of the manufacturing process to be able to identify which hazardous substances were being used. Dedi maintained that it was not about getting rid of the industries, but about taking care (menjaga) of industrial assets in a residential neighbourhood. Accommodating residents' discontent would minimize conflict, he felt.

\section{Pekalongan}

The issues in the Pekalongan neighbourhood (Cangkring) that I studied were different, but the basic problem of state services being hijacked by intermediate classes was the same. At issue here was the absence of public facilities due to bad urban planning. The other problem was the lack of clean water, as the neighbourhood lay beyond the boundaries of the municipal water supply. Shallow local wells contained high levels of dissolved chemicals and suspended solids typical of the town's coastal areas. Bypassing reluctant village officials, community representatives went to the municipal government to request a deep well. Although the area technically fell outside municipal infrastructure planning, the government accepted the proposal. The municipal authority also granted the community permission to distribute the water from the government-facilitated communal well and to charge households for the electricity used by the pump. In short, their first encounter with public officials immediately produced a real sign of recognition. One of the central figures in this Pekalongan initiative was Turah, who worked full-time in a textile factory. He had learned about water and electricity management from his company. He later successfully asked the municipal government to improve the pump, to install a water tank and, even, to build a small office so the water administration would no longer be run from a residential house.

Efforts to bring 'life' into the recently settled community extended to the conversion of abandoned land into a fish pond and a nursery for medicinal and cooking plants to accommodate fishermen losing their income as a result of the declining fishing economy. A few hectares of this unused land were actually borrowed from Turah's own company. The company went further and offered the community a loan to develop fishbreeding ponds. These efforts also enabled the low-income residents of another nearby neighbourhood and its surrounding communities to 
improve their economy and make better use of the environment. In addition, residents brought a sense of normalcy into the community that previously had no legal entitlement by simply naming their street, in order to enable outsiders to identify them as a community and to find an address. They saw street-naming as an inaugural effort for social recognition. (Even so, some even more 'local' figures initially pulled out the street signs until their 'permission' had been sought).

The municipal government is proud of having brought social and environmental development to a previously non-recognized and disadvantaged community. It regards the work in Cangkring, including the collaboration between the residents and industrial firms, as a model for its programme in poverty alleviation and environmental management of slum areas. ${ }^{14}$ It invited Turah and some of his colleagues to share his experiences in deep-well drilling and water management with other neighbourhoods around Pekalongan. Turah now has easy access to government officials including the mayor, to lawmakers and corporate agencies. They recognize his role as mediator connecting impoverished urban residents with the authorities.

Morever, Turah brought the fishermen to the mayor in the government offices to explain their problems. The mayor responded by ordering the fisheries authority to strictly oversee the harbour and the fish auction centre to protect the fishermen. This helped revive the fisheries economy in northern Pekalongan. The government also facilitated the construction of houses for fishermen along the coast. The mayor was chairman of the local Golkar branch. Turah then decided to join Golkar and campaign for him at the next local election. He said he was impressed that the mayor had kept his promise of rehabilitating the health, education and housing conditions of the poor in his neighbourhood. His neighbours did not blame him for joining the New Order party Golkar - they appreciated what he had done for them. Turah said that being close to the mayor had been the only way to bring people's aspirations to the correct authorities.

Initiatives by local residents in Cilegon and Pekalongan reveal the limitations of intermediate-class patronage as democratization deepens at the local level. Residents wanted direct contact - patrons were obstacles who distanced them from the state and the companies, and who seized

14 Certain individuals within the municipal government were credited in the national media for the success of these poverty alleviation and slum environment management programmes (Gatra, 13 February 2008; Radar Pekalongan, 11 June 2010). However, the reports made almost no reference to the role played by community figures like Turah. 
rents that should have gone to the marginalized. Contrary to those scholars who argue that democratization is strengthening the role of predatory intermediate classes, my close observation in these two places (which may indeed not be representative of all of Indonesia) shows that sometimes democratization is weakening their power. Regular free and fair local elections are allowing residents to act on their frustration with the neighbourhood-based 'elites' whose intimidation and flattery have long blocked their own access to state and corporate services. As they built their own direct links with the town's major economic and political forces, they built loose, semi-institutionalized alternative alliances to defend their own interests.

\section{Working Class and Changing Class Relations}

These neighbourhood experiences in Cilegon and Pekalongan expose two somewhat contradictory class dynamics in the semi-urban communities of industrializing provincial towns. One is a long-standing pattern of what might be called domination by predatory intermediate classes. The other is a counter-movement from below. The first pattern arose as local economic actors became incorporated into a modern industrial economy. The industries' need for informal contract labour privileged local entrepreneurs - neighbourhood notables and public officials - who deployed 'non-market' mechanisms to recruit workers on exploitative terms. These outsourcing agencies made good profits for themselves. Their bargaining position with the big companies rested on 'traditional' claims to represent the community, which in reality involved the capacity to pose threats.

Moreover, political decentralization actually strengthened the position of these local operators, who were seen as patrons by their own communities. Lacking a populist agenda to rally sympathy from the masses compelled the local government to work through intermediaries such as religious leaders and other influential big men. Where industry is less intrusive, such as in Pekalongan, the failure of the municipal government to reach people in urban peripheries leaves space for similar operators. Using threats, intimidation and local sentiment, they wheedle fishermen and new settlers out of their money while making themselves indispensable to local officials. In both towns, neighbourhood-based 'elites' use their access to bureuacratic and corporate resources mainly for their own purposes.

These arrangements clearly come at a cost to underprivileged urban classes, who, as underemployed subcontracted labourers, are left almost 
entirely without protection. The dissatisfaction among the unemployed in particular results in aggressive behaviour and criminality. Fishermen attribute their deteriorating subsistence to industrialization as well as to extortionate practices by intermediate-class local elites. All struggle to access local-government welfare services that could relieve their distress.

This chapter has examined a counter-movement from below in the two neighbourhoods studied. Democratization and decentralization have opened up a little-noticed new arena for workers, one that is located in their semi-urban kampung residential neighbourhoods. Here the old agrarian patron-client relations are in decline, while the harsh divide between labour and capital is somewhat softened. Dissatisfaction with the local figures and small capitalists who used to provide protection and certainty - people this chapter has identified as 'intermediate classes' - is growing. Meanwhile, full-time industrial workers, who would normally rely on traditional relations to defend them from harsh industrial exploitation (Elmhirst 2003; Wolf 1992), are now likely to be in a relation with less tension with their industrial employers. In my neighbourhoods they even became intermediaries for the industries' CSR programmes towards the local community. Some have found themselves becoming trusted intermediaries for channelling state welfare schemes in neighbourhoods previously beyond the state's reach. These developments have placed these mediating full-time workers into a loose alliance with lower urban classes, including the informal working class. This new alliance is quite unlike that observed between industrial working classes and intellectuals belonging to the urban middle classes during the 1990s (Ford 2009; Hadiz 1997; Kammen 1997; La Botz 2001).

Semi-urban poor neighbourhoods face a myriad of difficulties. Workers who live there become engaged in social activism. Their embeddedness in the everyday struggle of their own communities has shifted their arena of engagement away from the point of production towards their kampung. These permanent workers have a commitment to the industries, which have given them secure jobs and prestige. They realize that industrial decline would affect the livelihood of the entire town. Their attachment both to their local society and to the state and capital allows them to bridge the two, bypassing the authority of the old intermediate classes.

These initiatives have seen citizens re-engage with the state rather than building a different logic of power separate from the state and the companies. The activism parallels Indian experiments with community politics, which are also redefining the relationship between society and the state. Partha Chatterjee (2004) argues that alternate, somewhat informal, associations at the neighbourhood level ensure members' social well-being 
even when surrounded by urban hardship. The associations facilitate 'the duties of good citizenship' (Chatterjee 2004:60). This is, in the Indian context, what Chatterjee, following Michel Foucault (1991), calls 'governmentality'. It is the capacity of communities not recognized as part of civil society to 'claim the benefits of various governmental programs [...] [by] bending or stretching [the] [governmental machinery and] rules because existing procedures have historically worked to exclude or marginalize them'.

\section{Closing Remarks}

Post-Suharto local politics have empowered local actors by means of frequent local elections combined with the effective decentralization of government policy and resources allocation. Democracy has been deepened as civil society has grown (Erb, Priyambudi Sulistiyanto and Faucher 2006; Erb and Priyambudi Sulistiyanto 2009; Schulte Nordholt and Van Klinken 2007 b). Also in Indonesian provincial towns, democracy has created more room to manoeuvre for independent social sectors such as entrepreneurs, NGOs activists and concerned intellectuals. They are particularly keen to take their distance from 'elite patronage' (Van Klinken 2009:157). This chapter has explored how the dominance of the intermediate classes in the provincial towns, such as traditional leaders, small capitalists and local state officials, is being contested by the urban underclasses demanding state welfare services and corporate compensation to protect them from the consequences of their largely informal employment. As these underprivileged workers become incorporated into the market economy through industrialization, and as democracy makes the state more present to them, some are able to throw off their role of traditional clients to the town's intermediate classes at the local-neighbourhood level. These are classes with differential access to political procedures and institutional practices as compared to the powerful neighbourhood-based elites at many different levels. Their different forms of capital, defined in social and cultural terms, has enabled them to create political space in their respective localities to defy established elites. Their experiences of exclusion lead to initiatives that become a rallying point for citizenship claims even in distant areas of the country. These factors altogether allow the industrial working class to secure the position as new intermediary for local residents.

Engagement in these mediating functions does not necessarily lead to social mobility of industrial workers. In spite of their different life chances 
by comparison with the underemployed informal-sector workers, given their higher status in the workplace, industrial workers remain part of their own community and are involved in the same everyday struggles as all its other residents. The local neighbourhood with its social predicaments, therefore, can form the basis for a new working-class identity and solidarity. The lesser degree of tension in industrial relations, wherever a level of wages and working conditions considered to be just and sufficient by workers discussed here are in place, also marks the shift of the arena of working-class struggle from the shopfloor to the residential neighbourhood.

The sense of justice does not melt as workers leave the shopfloor. Some may object that my observations imply that full-time workers will simply become the new predatory intermediate classes in these towns. Further research is required to prove or disprove this point. As it is, I agree with the conclusions of Diane Davis (1999), who observed similar transformations in Latin America. Rather than exacerbating the 'state and civil society divide' or creating 'dichotomization', she wrote, an ongoing transformation is bringing representations 'of this inaccessible state down to a more attainable and manageable level' and thus place citizens back in a 'social contract' with the state. 